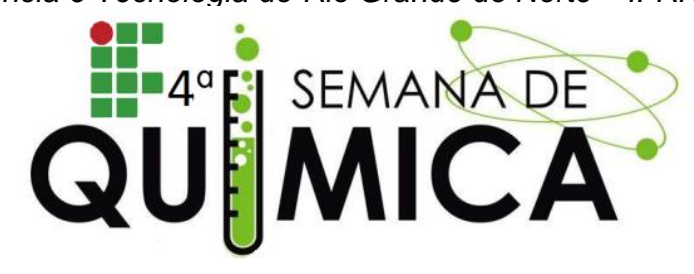

\title{
SIMULAÇÃO POR DINÂMICA MOLECULAR DO ÍONS CITRATO EM AMBIENTE PROPÍCIO A FORMAÇÃO DE INCRUSTAÇÕES CARBONÁTICAS
}

BARRETO, E. L. M. (IFRN); ALVES, L. S. (IFRN); SENA, C. P. S. (IFRN).

Palavras Chave: Carbonato de cálcio, dinâmica molecular, ácido cítrico.

\section{INTRODUÇÃO}

Incrustações inorgânicas podem ser definidas como a deposição de sais de baixa solubilidade nas paredes de poços, tubulações e em tanques. Na indústria petroleira, a ocorrência destas formações representa prejuízos financeiros, desencadeando, dentre outras coisas, o comprometimento da qualidade e do escoamento do óleo pelas tubulações. 0 principal agente incrustante é o carbonato de cálcio $\left(\mathrm{CaCO}_{3}\right)$, e sua formação, ocorre principalmente pela mistura de águas incompatíveis, como é o caso da água de produção e a água de injeção, durante os processos de recuperação do petróleo, quando os íons $\mathrm{Ca}^{2+}$ presentes no sistema reagem com o bicarbonato $\left(\mathrm{HCO}_{3}{ }^{-}\right)$(REIS et al, 2011). Sendo assim, o presente trabalho apresenta resultados preliminares de uma pesquisa que visa realizar um estudo teórico através de simulações por dinâmica molecular (DM), com o objetivo de analisar a atuação do íon citrato como inibidor de incrustações inorgânicas.

\section{METODOLOGIA}

O processo de simulação (figura 1 ) do íon citrato em ambiente aquoso onde íons cálcio, sódio e cloro estão presentes em concentrações baseadas em análise química de água de produção de um poço de petróleo (FROTA, 2009). A molécula de citrato foi construída através do software Avogadro e otimizada usando a função de base HF/6$31 \mathrm{~g}(\mathrm{~d})$. As cargas atômicas foram derivadas pelo método RESP.

Figura 1 - Fluxograma do processo de simulação por dinâmica molecular.

\section{Simulação}

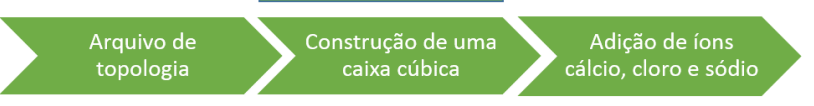

\section{Minimização Dinâmica de Dinâmica de} restrição equilibrio

\section{RESULTADOS E DISCUSSÕES}

A dinâmica de produção foi realizada sobe um ensamble NVT, utilizando o software GROMACS com campo de força AMBER. O íon citrato foi simulado por 25 ns em um caixa cúbica de volume $28 \mathrm{~nm}^{3}$ a $300 \mathrm{~K}$. Foram adicionadas 846 moléculas de água, 16 íons $\mathrm{Ca}^{2+}, 15$ íons $\mathrm{Na}^{+}$e 43 íons $\mathrm{Cl}^{-}$para contrabalancear as cargas. A figura 2 mostra a conformação de menor energia obtida pela simulação, onde pode-se observar que o íon citrato atraiu para suas carboxilas 4 íons $\mathrm{Ca}^{2+}$.

Figura 2 - Conformação de menor energia obtida pelo íon citrato simulado por 25 ns na presença de íons $\mathrm{Ca}^{2+}$.

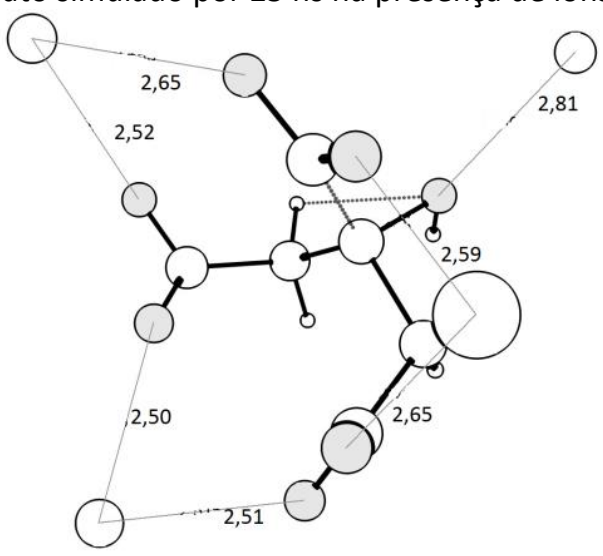

\section{CONCLUSÃO}

A partir deste estudo chega-se à conclusão de que a molécula de citrato pode ser usada na captura de íons cálcio, para inibição da formação de carbonato de cálcio em ambientes que apresentem altas concentrações de $\mathrm{Ca}^{2+}$. Ressalta-se a importância da análise posterior da interação entre a molécula e os contra-íons.

\section{REFERÊNCIAS}

FROTA, T. M. P. Incrustação em um poço produtor de petróleo e gás natural: um estudo de caso. [s.l.] UFRN, 2009.

REIS, M. L. P. et al. Deposição mineral em superfícies: problemas e oportunidades na indústria de petróleo. Revista Virtual de Química, Niterói, v. 3, n. 1, p 2-13, mar. 2011. 